\title{
MENTORING IN THE PROFESSIONAL DEVELOPMENT OF PRIMARY AND SECONDARY SCHOOL TEACHERS
}

\author{
Eliška Suchánková ${ }^{\boxplus}$, Karla Hrbáčková
}

${ }^{1 ⿴}$ Department of Pedagogical Sciences, Faculty of Humanities, Tomas Bata University in Zlín, Nám. T. G. Masaryka 5555, Zlín, 760 01, Czech Republic, +420 576037303, suchankova@fhs.utb.cz

${ }^{2}$ Department of Pedagogical Sciences, Faculty of Humanities, Tomas Bata University in Zlín, Czech Republic

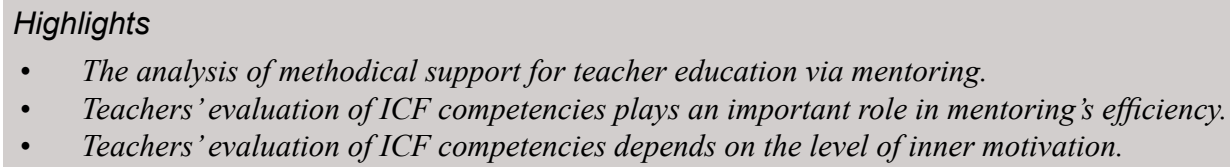

\section{Abstract}

The contribution presents the results of research focused on analysing methodical support for teacher education via mentoring, and familiarizes itself with the ascertained efficiency of the established mentoring programme in pilot schools in the Zlín region from the perspective of primary and secondary school teachers. The research shows that teachers' evaluation of their own professional coaching competencies plays an important role in the perception of the mentoring's efficiency. The higher the level of mastery of these competencies that the teachers attain in their own opinion, the better mentors they feel they are, the more they perceive mentoring as beneficial, and the more they use it in practice. At the same time, it is shown that the evaluation of own professional coaching competencies depends on the level of inner motivation to become involved in the mentoring course.

\section{Keywords}

Mentoring, methodical support, teachers' professional development, mentor, professional coaching competencies, efficiency of mentoring

Suchánková E., Hrbáčková K. (2017) "Mentoring in the Professional Development of Primary and Secondary School Teachers", Journal on Efficiency and Responsibility in Education and Science, Vol. 10, No. 1, pp. 7-15, online ISSN 1803-1617, printed ISSN 2336-2375, doi: 10.7160/eriesj.2017.100102.

\section{Introduction}

The National Programme for the Development of Education in the Czech Republic (Národní program rozvoje vzdělávání v České republice, 2001) presented six main strategic lines of educational policy in the Czech Republic, among which it ranked mentoring and the evaluation of the quality and efficiency of education. The strategic intention to support quality education and teachers as its key prerequisite is also currently mentioned in the Strategy for Education Policy of the Czech Republic until 2020 (Strategie vzdělávací politiky České republiky do roku 2020, 2014). Methodical support for teachers must be based on a certain need, and subsequently from a specific evaluation. The methodical support will be most effective where teachers feel they have the greatest reserves.

One of the forms of professional teacher support is represented by mentoring, i.e. collegial support by the more experienced to the less, and by the relationship of the mentor accompanying and supporting the mentee (Pol, 2007). Mentoring deals with support for the teacher's professional development in various phases of their career path. During mentoring, teachers begin with their own professional experiences, and regulate their own professional development under the mentor's supervision. Responsibility for the teaching process is transferred to the pedagogue, which then strengthens their professional competency, internal motivation to self-educate, and perception of their own success (Šneberger, 2012a, 2012c; Hrbáčková et al, 2014). Mentoring relationships enriches both parties - the one that learns and the one that teaches (Nový termín - mentoring, 2009). Teachers do not benefit from effective mentoring, i.e. a good mentoring relationship, not only at the beginning of their career path, but also in subsequent years of their pedagogical practice (Jonson, 2008). Thanks to mentoring, teachers gain a new perspective on the students' development possibilities, which is reflected in the increased quality and efficiency of teaching and learning.

With the gradual introduction of mentoring to schools, its quality must also be evaluated. Nowadays, however, measuring the quality of education is increasingly focused on structural quality, i.e. on objectively measurable criteria (e.g. comparison of individual students' results) rather on the process of quality, which focuses on the teacher's professional competencies and the dynamics of the educational process (Šneberger, 2012b). The contribution presents the results of research focused on analysing methodical support for teacher education via mentoring. The contribution familiarizes itself with the ascertained efficiency ${ }^{1}$ of the established mentoring programme in pilot schools in the Zlín region.

Mentoring is one of the less traditional forms of support for pedagogical workers' professional development, based on their individual needs, targeted methodical assistance and mutual teaching (Dlouhodobý záměr vzdělávání a rozvoje vzdělávací

\footnotetext{
1 The term efficiency in the evaluation sense is understood as a certain general quality that is distinguished by the fact that given inputs correspond with outputs that have a certain required level (Průcha, Walterová and Mareš, 2009). The efficiency of mentoring is perceived in accordance with Hawkins's conception of the term efficiency (1950) as a certain abstract quality; as a sensation of competence or ability in a situation when a person is contented by objects of their activities. In our case it represents teachers' evaluation of their own professional coaching competencies, the perceived benefit and utilization level of the mentoring, and the reservations and limits of own mentoring work.
} 
soustavy České republiky na období 2011 - 2015, 2011), moreover, mentoring is an innovative method of supporting the quality of education, having much in common with coaching and supervising. The aim of mentoring is to increase the quality and efficiency of pedagogical work, and to provide teachers with information and personal support (Syslová, 2013).

Contribution of mentoring is particularly evident in the professional competency, reflective practise, professional renewal, and in the psychological area (e.g. self-esteem, satisfaction from helping), collaboration (collegial interaction) and teacher leadership (Huling, 2001).

In professional literature, mentoring and the introduction of a new teacher is perceived as one of the basic components of a quality teacher and quality school (Irvin, 1985; Evertson and Smithey, 2000; Tomková et al, 2012). Statistical data shows that teachers who received high-quality and systematic professional support leave the teaching profession considerably less frequently than teachers who did not receive such support (Ingersoll and Smith, 2004).

In the Czech Republic, certain professional support is more common for new teachers in the form of support from introducing teachers, but teachers with more years of practice are facilitated less professionally. At the same time, mentoring plays an important role not only in the case of support for the development of new teachers' professional skills (competencies), but particularly in the process of support for the professional growth of teachers who strive to increase the quality of their teaching (Hrbáčková et al, 2014). According to current research, individualized support via mentoring has an efficiency of over $60 \%$ (referring to changes in teacher's own practise achieved in the given form of education) compared to the approximately $15 \%$ efficiency of traditional seminars (Šneberger, 2012a). Thus, according to the Strategy for Education Policy of the Czech Republic until 2020 (Strategie vzdělávací politiky České republiky do roku 2020, 2014), in future years every teacher should not only have the option of utilizing further education programmes, but also have access to individual support based on a reflection of their own pedagogical activity under professional supervision, at any stage of teacher's career path. This should result mainly in support for effective forms of the mutual sharing of experiences among pedagogues, the position of a mentor for the teacher should be defined in the career system, a mentoring skills development system should be created for pedagogues, etc. Thus, the offer of methodical support via mentoring should become more accessible in the coming period.

The mentor and mentee enter the mentoring process. The mentor is an experienced adviser whom the mentee trusts. The mentor is a ,side by side" guide, who assists, shares, and shows a genuine interest (Vonk, 1993, Baird, 1993 In Clutterbuck, 2004). The mentee (also protégé, intern, programme client, service client) is an individual who is introduced to practice in the field by an experienced expert, they are the mentor's partner in the so-called mentoring relationship, and they are a client of the mentoring programme (Kraus et al, 2005; Jonson, 2008; Brumovská and Seidlová Málková, 2010). The client's education and personal growth is an important part of the mentoring process, but the mentor should also profit considerably (National Academy of Sciences, 1997). Within the scope of the mentoring relationship, the mentor creates conditions for the mentee which are suitable for gaining new knowledge and developing their interests and talent (DuBois and Karcher, 2006).

From a broader perspective, mentoring can be performed anytime, anywhere and by anyone; it can be a one-off intervention or a life-long relationship (Shea, 2002). A healthy and safe mentoring relationship is based on trust, a non-judgemental approach and shared experience - this is the basis of a successful mentoring programme (Jonson, 2008; Píšová, Duschinská et al, 2011).

A teacher gains mentoring skills from their own experience, and also from mentoring training. Undergoing mentoring training not only benefits the mentor's future clients, but also improves the quality of the mentor's schooling - the teacher themselves. In the mentoring process, the mentor may appear in multiple roles (Píšová, Duschinská et al, 2011; EDOST, 2012), whereby each of the roles places specific requirements on knowledge, skills, experience and abilities, i.e. the mentor's competencies. The mentor should be a good listener, they should be sensitive to the mentee's needs, and not judge or condemn (Jones, 2008; Zachary, 2009). They should be an educated and experienced person with high standards of behaviour and moral values worth following (Medlíková, 2013). The mentor should understand themselves and others, they should have clear objectives, they should be communicative, have a sense of humour and balance and an interest in developing others, they should build relationships on trust, they should be creative and self-educate, and have the ability to reflect and self-reflect (Clutterbuck, 2004). Furthermore, the so-called ICF basic professional coaching competencies (ICF Czech Republic, 2013) are considered. The competencies include foundations for work with the client (adherence to a code of ethics and professional standards, definition of coaching agreement), the creation of a mutual relationship (creation of trust and closeness with the client, coaching position), effective communication (active listening, use of strong questions, direct communication) and support for teaching and achieving results (developing self-awareness, designing events, planning and stipulating objectives, managing development and responsibility).

When introducing mentoring to schools, the so-called quality pedagogical practice competencies represent the basic professional quality framework (Šneberger, 2012b). According to the focus, we can define these as competencies in the area of professional development, teaching environment and conditions, teaching planning and evaluation, schools and communities, communication and the teaching process. Along with the definition of the teacher's competencies, the criteria and indicators of the quality of teaching are propounded by a number of national and international quality standards, e.g. International Standard for the Work of the Teacher and Lecturer RWCT (Mezinárodní standard práce učitele a lektora RWCT, 2007), International Pedagogical ISSA Standards (Mezinárodní pedagogické ISSA standardy, 2002), Competent Educators of the 21st Century: ISSA'S Principles of Quality Pedagogy (2010) Competent Educators of the 21st Century: The ISSA International Professional Quality Framework (Kompetentní učitel 21. století: Mezinárodní profesní rámec kvality ISSA, 2011), Framework of Professional Qualities for Teachers (Tomková et al, 2012) as a result of the Path to Quality national programme (Cesta ke kvalitě, NÚV, 2011-2015) and other overviews of teachers' professional qualities, e.g. Framework of Professional Qualities 
for Kindergarten Teachers (Syslová, 2013), Competencies of Quality Pedagogical Practice (Hrbáčková et al, 2014) etc.

Rhodes and DuBois (2008) have prepared a so-called model of the process of mediating the benefits of mentoring, by which they point to the fact that mentoring is beneficial if the mentoring relationship fulfils partial signs of quality such as trust, empathy and closeness. The advantages of mentoring are considered to be own professional development, better analysis of problems and own performance, insight into practice, increased contemplation, increased self-awareness etc. (Hobson, 2003).

Motivation to train the mentor and to use mentoring support, which also relates to the system of introducing mentoring in schools as a professional methodical support, are considered as key in the mentoring process. Although we see participation in the mentoring programme as essential, this participation is meaningless if it lacks an element of voluntariness. The quality of the mentoring support is decided on by how the school, teachers and public view professional qualities, the teacher's competencies and their responsibility towards society. A methodical support system established in a so-called topdown manner may be perceived by teachers as an externally threatening evaluation in favour of the norm (evaluation of the quality of the teacher's performance) rather than as positive feedback which would motivate them further to realize and utilize the methodical support.

If the teacher has time and space for own decision-making, and suitable conditions for self-education and self-development, mentoring becomes an advantageous opportunity for the development of self-regulation (auto-regulation) of the mentor and mentee, and the teacher then becomes a true expert in their profession. (Hrbáčková et al, 2014)

In the research, we focused on examining the efficiency of a mentoring course (training) (in the Quality programme realized by the Regional Centre for Further Professional Development and the Education and Lifelong Learning Centre for the Zlín Region) from the perspective of teachers who underwent this training (i.e. mentors). The implied research follows the pilot research realized in the initial phase of introducing the mentoring programme to schools (Hrbáčková et al, 2014), which focused on examining the level of quality of teaching by trainee primary and secondary school teachers in the Zlín region, and on the benefit of methodical support for teachers.

\section{Materials and methods}

In the research, we focused on examining the efficiency of the mentoring course from the perspective of primary and secondary school teachers in the Zlín region, who completed an accredited mentoring course intended for teachers in the Zlín region.

The program was 9 months long (March 2014 - November 2014) and 10 pilot schools from the Zlín region were involved in it. Training of mentors was conceived in the form of contact teaching and practical exercises; concrete examples of pedagogical situations and case studies from participants' practise were a part of the training. The content of mentor training consisted of four two-day modules of 40 hours of theory and 50 hours of practise (3x two-day modules, $3 \mathrm{x}$ one-day supervision meeting, $3 \mathrm{x}$ individual supervision mentoring support and classroom and observations with feedback, observation of one's own mentoring work, discussion about development plan, Skype contact and written consultation). Non-contact teaching was also a part of the training.

We were interested in the teachers' awareness of mentoring before starting the mentoring course, the reasons that lead the teachers to participate in the course, and how the teachers evaluate their own professional coaching competencies after completing the mentoring course. We also examined the perceived benefit and utilization level of the mentoring, and the reservations and limits of own mentoring work.

We analyse whether there is a connection between selfmotivation to participate in the mentoring course, the school's requirements and the teachers' level of awareness of the mentoring. In addition, we examined whether there is a connection between self-motivation to participate in the mentoring course, the perceived level of mastery of professional coaching competencies, whether the teachers feel that they are mentors after completing the course, and the benefit and utilization of mentoring in own practice. At the same time we examined whether there are differences in perceiving oneself as a mentor, depending on the extent of school requirements to participate in mentoring course.

We assumed that the rate of inner motivation will depend on the extent of school requirements to engage in the course, and the higher the inner motivation of teachers is, the higher their awareness about mentoring is. At the same time we assumed that the stronger demand of schools to join the course is, the lower the awareness of teaching about mentoring is.

Furthermore, we assumed that the inner motivation of teachers would positively correlate with much the teachers feel they are mentors, with professional coaching competencies and with the extent to which they use mentoring practise and with perception of mentoring contributions.

We also assumed that the rate of professional coaching competencies positively correlates with the fact that how much the teachers feel they are mentors, with using mentoring practise and with the extent to which teachers perceived the mentoring course as beneficial.

We assumed that the teachers who participated in mentoring course at the school request, would feel mentors to a lesser extent that the teachers who participated in the course without school requirement.

On the basis of the research objective, we chose a quantitative approach. The research group consisted of 30 respondents mentors, who participated in the training $(\mathrm{N}=30)$. It was an exhaustive selection group (i.e. all the teachers involved in the mentoring training).

For the data collection, we used a 26-item questionnaire divided into four parts:

1) period before starting the mentoring course - motivation, awareness of mentoring (items 1-3 of the questionnaire)

2) managing ICF basic professional coaching competencies (2013; hereinafter ,professional coaching competencies”) in 
the areas of creating foundations for work with the client (items 4-5 of the questionnaire), creating a mutual relationship (items 6-7 of the questionnaire), effective communication (items 8-10 of the questionnaire), and support for teaching and achieving results (items 11-14 of the questionnaire)

3) period after completing the course - benefit and level of practical utilization of mentoring (items 15-23 of the questionnaire)

4) benefit of the course in professional development, reservations and limits of own mentoring work (items 24-26 of the questionnaire)

Parts 1-3 are measured with the help of self-reflection Likerttype scales $(1=$ very little to $5=$ very much), while part 4 is measured with the help of open questions.

To analyse the data, we used correlation analysis, the Kruskal -Wallis test and One-factor analysis of variance ANOVA. In the study, we worked with data used in Lepková's research (2015). ${ }^{2}$ The data was processed using the IBM SPSS Statistics (V21.0.0) programme.

\section{Results}

The teachers' level of awareness of mentoring before starting the course (part 1 of the questionnaire) was relatively low. $70 \%$ of the participants in the training stated that before starting the mentoring course they had only very little or little information; only $3 \%$ of teachers had received more information (Figure 1 ).

Note: The awareness of teachers was measured on a five-point scale, the value 5 was no represented in the results.

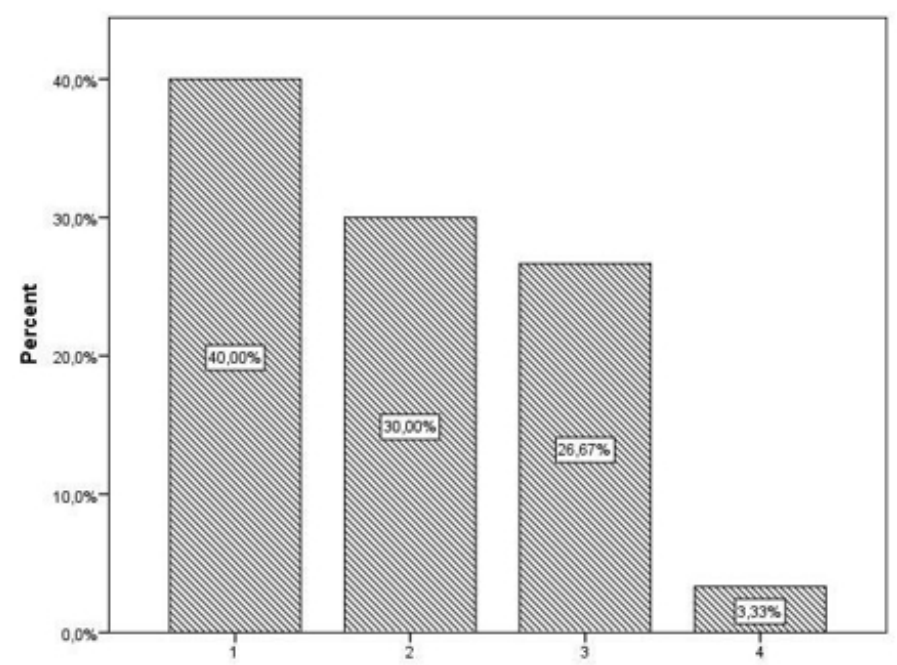

Figure 1: Teachers' awareness of mentoring

To a large extent, the teachers' entry into the mentoring course was due to the school's requirement (57\%), while in $30 \%$ of cases the school's requirements were not decisive for participation in the course (Figure 2).

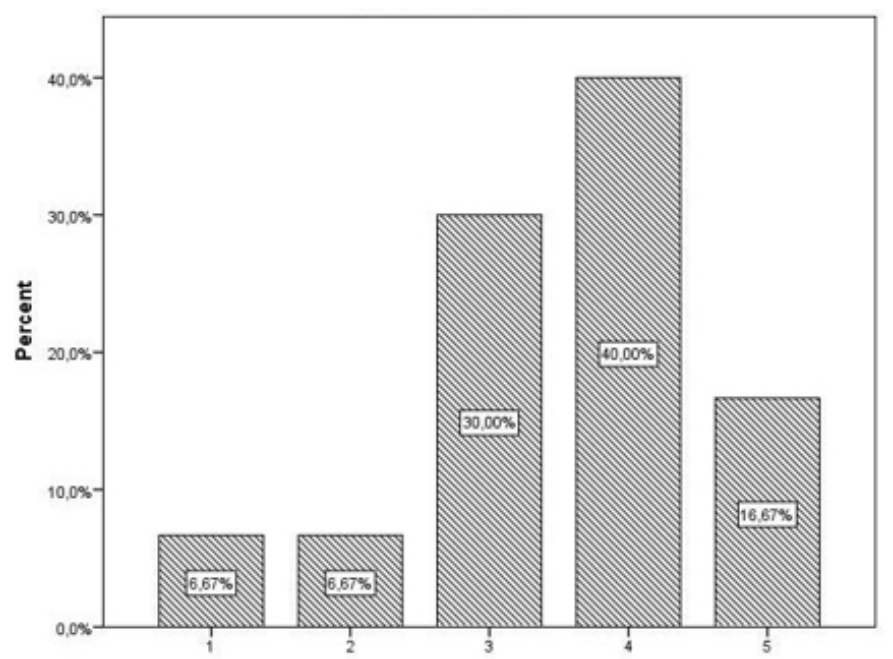

Figure 2: School's requirement for joining the mentoring course

Self-motivation to participate in mentoring course is represented in different extent. $17 \%$ of the teachers have strong motivation, while for $13 \%$ of the teachers' motivation is very weak. Other values are represented to the same extent (23.3\%). (Figure 3)

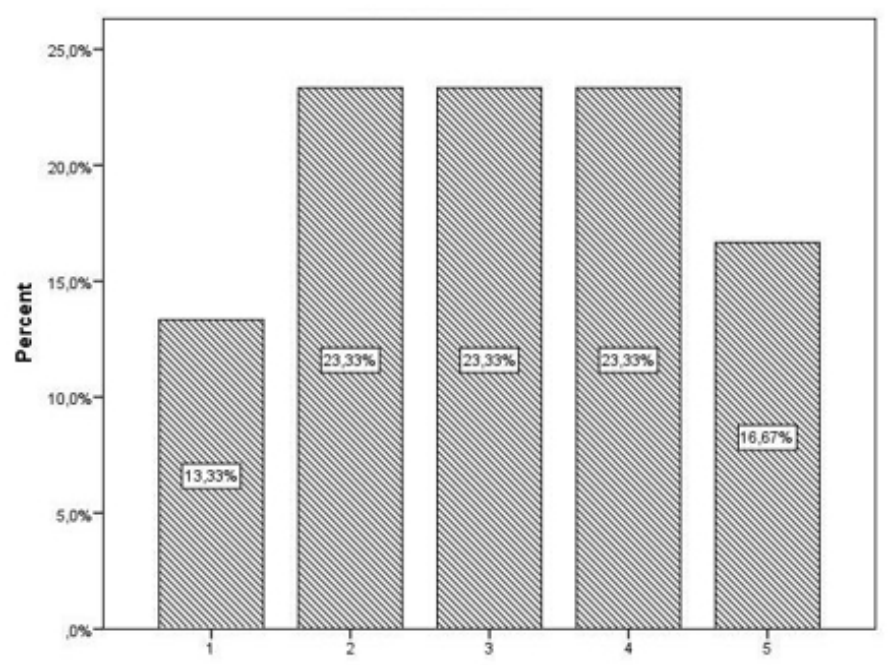

Figure 3: Self-motivation for joining the mentoring course

Teachers who participated in the course on the basis of the school's requirements show the lowest level of self-motivation $(\mathrm{M}=2.40, \mathrm{SD}=1.14)$, while in the case of teachers who did not participate in the course on the basis of the school's requirement, a high level of self-motivation prevails $(\mathrm{M}=5.00, \mathrm{SD}=0)$. (Table 1, Figure 4)

\begin{tabular}{|c|c|c|c|}
\hline $\begin{array}{c}\text { School's } \\
\text { requirement }\end{array}$ & $\mathrm{N}$ & Mean & St. deviation \\
\hline 1 & 2 & 5.00 & .000 \\
\hline 2 & 2 & 4.50 & .707 \\
\hline 3 & 9 & 3.22 & 1.394 \\
\hline 4 & 12 & 2.67 & 1.073 \\
\hline 5 & 5 & 2.40 & 1.140 \\
\hline Total & 30 & 3.07 & 1.311 \\
\hline
\end{tabular}

Table 1: Self-motivation according to the extent of the school's requirement

The school's requirement to participate in the mentoring course has a negative correlation (Table 2) with teachers' selfmotivation to participate in the course $(\mathrm{r}=-.508, \mathrm{p}=.004)$. The more the teachers are required to participate in the course, the lower their inner motivation.

The teachers' self-motivation to participate in the course has a positive correlation with their awareness of mentoring ( $\mathrm{r}$ $=.405, \mathrm{p}=.026)$. The higher the teachers' inner motivation,
2 This study uses data collected during the project IGA / FHS / 2013/008 Mentoring and Methodical Support of Primary and Secondary School Teachers in the Zlín Region. The data was partially used in the diploma thesis by Lepková (2015) as a sub-project output. Both the diploma thesis and this study are based on the same data, they differ in the way of data processing and partial results. 
the more information they have before the mentoring course. However, we simultaneously discover that the teachers' level of awareness is not connected to whether entry into the course was required by the school or not $(\mathrm{r}=-.067, \mathrm{p}=.726)$ even though, on the basis of the afore-mentioned results, one could expect that the stronger the school's requirement to enrol in the course, the lower the effort to obtain information will be (a negative correlation is shown, but is statistically insignificant). Thus, it's evident that teachers who are intrinsically motivated to enrol in the course are informed about mentoring regardless of whether enrolment in the course is also required by the school or not.

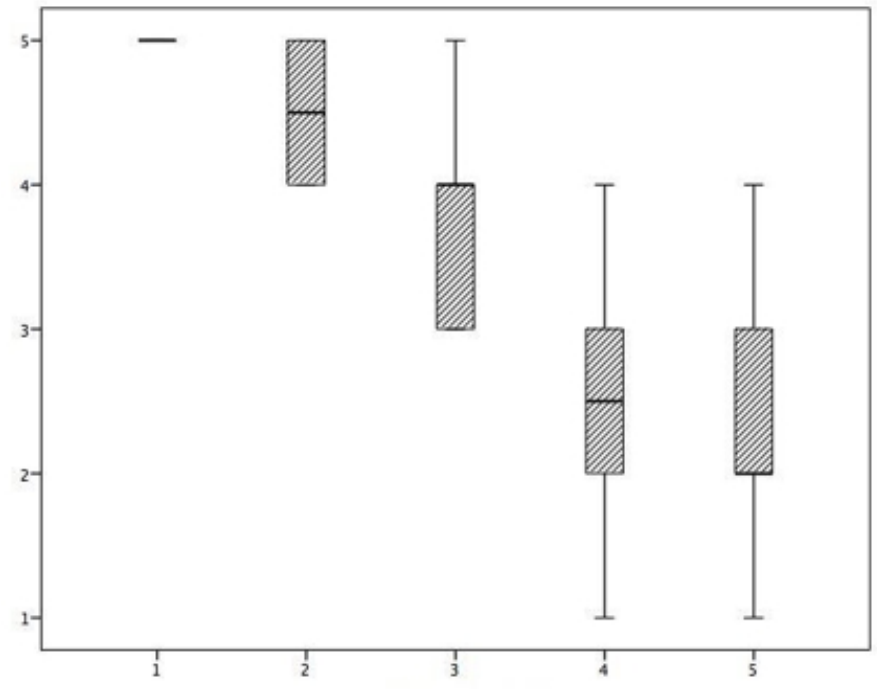

Figure 4: Self-motivation (y) according to the extent of the school's requirement $(x)$

\begin{tabular}{|l|c|c|c|}
\hline & $\begin{array}{c}\text { Self- } \\
\text { motivation }\end{array}$ & $\begin{array}{c}\text { School's } \\
\text { requirement }\end{array}$ & Awareness \\
\hline Self-motivation & - & & \\
\hline $\begin{array}{l}\text { School's } \\
\text { requirement }\end{array}$ & $-.508^{* *}$ & - & \\
\hline Awareness & .405 & -.067 & - \\
\hline
\end{tabular}

** correlation at significance level.01, * correlation at significance level.05

Table 2: Correlation of self-motivation, school's requirement, awareness (Spearman's rho)

During the training, participants in the course gradually mastered professional coaching competencies. We examined how teachers evaluate their mastery of these competencies after completing the mentoring course (part 2 of the questionnaire).

The highest level of competency mastery (Figure 5, Table 3) is achieved by teachers in the area „ICF 1 Creating Foundations for Work with the Client" $(\mathrm{M}=4.05, \mathrm{SD}=.648)$ and also in the area „ICF 2 Creating a Mutual Relationship” (M = 3.967, SD $=.556)$.

The teachers evaluate themselves positively in the area „ICF 3 Effective Communication" ( $\mathrm{M}=3.711, \mathrm{SD}=.508)$ and also in the area "ICF 4 Support for Teaching and Achieving Results" $(\mathrm{M}=3.342, \mathrm{SD}=.493)$, even though their evaluation in this area is the lowest of all the four areas.

The teachers believe that they are able to listen actively $(\mathrm{M}=$ $4.233, \mathrm{SD}=.728$ ) and adhere to a code of ethics and professional standards $(\mathrm{M}=4.167, \mathrm{SD}=.648)$; at the same time, they think that they have managed to create a relationship of trust and closeness with the client $(\mathrm{M}=4.133, \mathrm{SD}=.82)$. The teachers evaluate their ability to develop the client's self-awareness (M $=2.967, \mathrm{SD}=.615)$, to manage the client's development and responsibility $(\mathrm{M}=3.133, \mathrm{SD}=.73)$ and to use strong questions during contact with the client $(\mathrm{M}=3.167, \mathrm{SD}=.699)$ at a lower level.

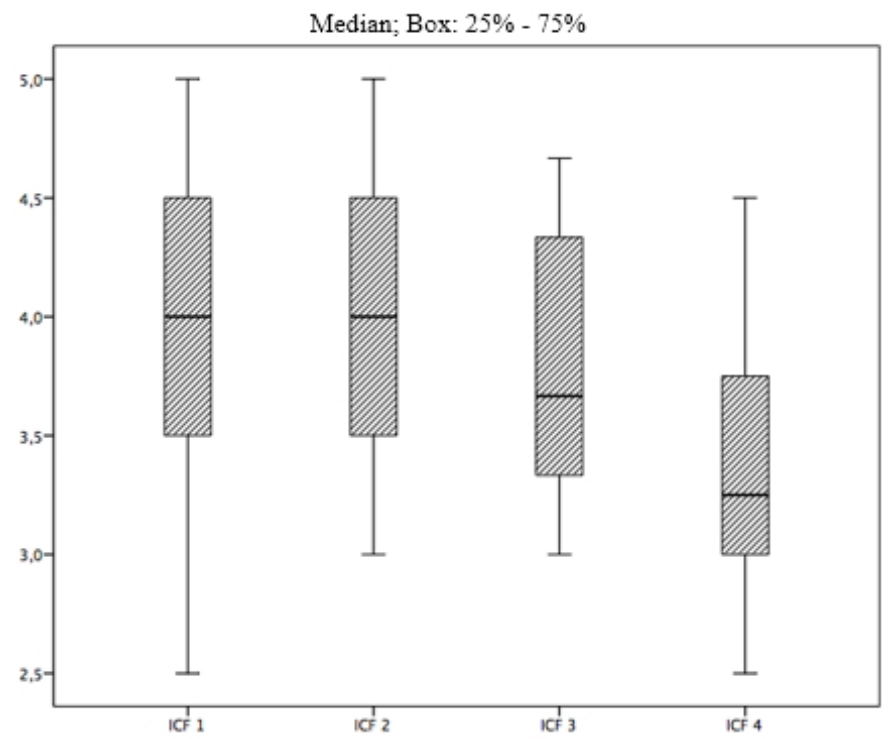

Figure 5: Mastery of professional coaching competencies in areas ICF 1 - ICF 4

\begin{tabular}{|c|c|c|c|}
\hline $\begin{array}{l}\text { Questionnaire } \\
\text { item }\end{array}$ & Professional coaching competence & Mean & $\begin{array}{c}\text { St. } \\
\text { deviation }\end{array}$ \\
\hline \multicolumn{4}{|c|}{ ICF 1 Creating Foundations for Work with the Client } \\
\hline 4 & $\begin{array}{l}\text { To what extent have you mastered } \\
\text { adherence to a code of ethics and } \\
\text { professional standards? }\end{array}$ & 4.167 & .648 \\
\hline \multirow[t]{2}{*}{5} & $\begin{array}{l}\text { To what extent have you mastered the } \\
\text { definition of agreement (contact) for work } \\
\text { with the client? }\end{array}$ & 3.933 & .828 \\
\hline & Mean value ICF 1 & 4.050 & .648 \\
\hline \multicolumn{4}{|c|}{ ICF 2 Creating a Mutual Relationship } \\
\hline 6 & $\begin{array}{l}\text { To what extent have you created } \\
\text { a relationship of trust and closeness with } \\
\text { the client? }\end{array}$ & 4.133 & .820 \\
\hline \multirow[t]{2}{*}{7} & $\begin{array}{l}\text { To what extent have you mastered your } \\
\text { position of mentor? }\end{array}$ & 3.800 & .761 \\
\hline & Mean value ICF 2 & 3.967 & .556 \\
\hline \multicolumn{4}{|c|}{ ICF 3 Effective Communication } \\
\hline 8 & $\begin{array}{l}\text { To what extent do you use active listening } \\
\text { during contact with the client? }\end{array}$ & 4.233 & .728 \\
\hline 10 & $\begin{array}{l}\text { To what extent have you mastered the } \\
\text { technique of direct communication with } \\
\text { the client? }\end{array}$ & 3.733 & .692 \\
\hline \multirow[t]{2}{*}{9} & $\begin{array}{l}\text { To what extent do you use strong } \\
\text { questions during contact with the client? }\end{array}$ & 3.167 & 699 \\
\hline & Mean value ICF 3 & 3.711 & .508 \\
\hline \multicolumn{4}{|c|}{ ICF 4 Support for Teaching and Achieving Results } \\
\hline 13 & $\begin{array}{l}\text { To what extent can you plan and set } \\
\text { objectives with the client? }\end{array}$ & 3.933 & .640 \\
\hline 12 & $\begin{array}{l}\text { To what extent can you design events for } \\
\text { the client? }\end{array}$ & 3.333 & .661 \\
\hline 14 & $\begin{array}{l}\text { To what extent can you manage the } \\
\text { client's development and responsibility? }\end{array}$ & 3.133 & .730 \\
\hline \multirow[t]{2}{*}{11} & $\begin{array}{l}\text { To what extent can you develop the } \\
\text { client's self-awareness? }\end{array}$ & 2.967 & .615 \\
\hline & Mean value ICF 4 & 3.342 & .493 \\
\hline
\end{tabular}

Table 3: Mastery of professional coaching competencies in areas ICF 1 - ICF 4 
Having completed the course (part 3 of the questionnaire), approximately a third of the teachers $(33.33 \%)$ feel competent in the role of mentor, and almost half of the teachers (46.67\%) feel that they are a mentor in part (teachers chose the mean value 3 on scale). Having completed the course, $20 \%$ of the teachers do not feel they are mentors. (Figure 6)

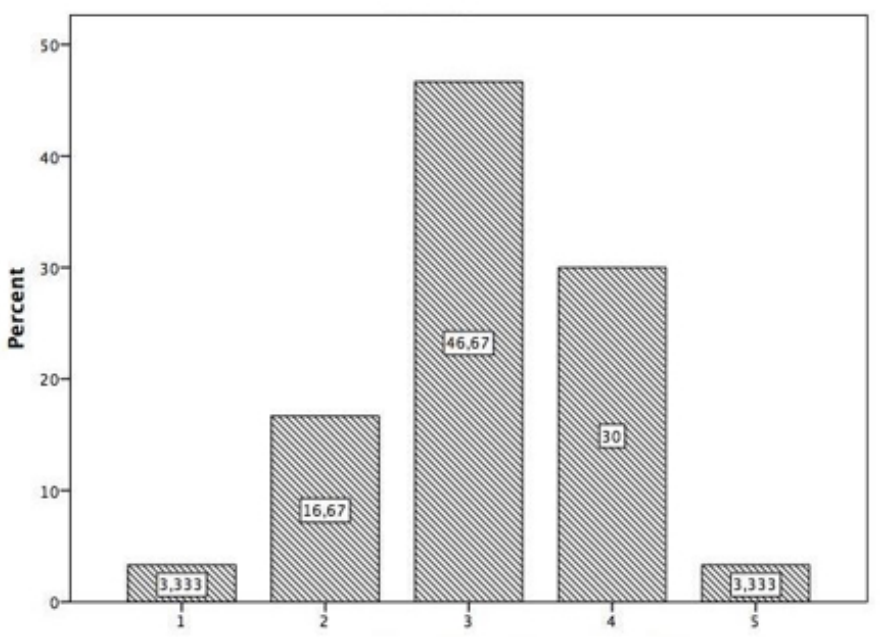

Figure 6: Feel competent in the role of mentor

The results suggest that the extent to which teachers feel to be mentors is not dependent on school requirements to participate in mentoring course $(p=.258)$. Teachers on who low requirements to join the mentoring course are placed achieve comparable results in how much they feel to be mentors, as well as teachers who are subjects to medium or high requirements. (Table 4)

\begin{tabular}{|c|c|c|}
\hline School's requirement & Mean & St. deviation \\
\hline Low $(1,2)$ & 2.500 & 1.000 \\
\hline Medium (3) & 3.110 & .782 \\
\hline High $(4,5)$ & 3.290 & .849 \\
\hline Total & 3.130 & .860 \\
\hline
\end{tabular}

Table 4: Differences in the extent to which teachers feel to be mentors based on school requirements

In the schools in which the mentors work as teachers, they use their skills partially in regular practice $(\mathrm{M}=2.956, \mathrm{SD}=.958)$. The reason may be the only partial creation of conditions for mentoring work by the school management $(\mathrm{M}=3.167$, SD = 1.234 ) and also lower interest in mentoring support by colleagues $(\mathrm{M}=2.5, \mathrm{SD}=.938)$. It's possible that in practice there are still deep-rooted fears of the inspection and evaluation of teachers' work, and many teachers also usually do not feel the need to significantly change their work $(\mathrm{M}=3.367, \mathrm{SD}=.928)$. Having completed the mentoring course, the teachers feel an effect on their own pedagogical work $(\mathrm{M}=3.833, \mathrm{SD}=.95)$, and they would also recommend other colleagues to become mentors $(\mathrm{M}$ $=3.667, \mathrm{SD}=1.093)$. The expectations of completing the course were partly fulfilled $(\mathrm{M}=3.467, \mathrm{SD}=1.106)$. (Table 5)

The teachers perceive (part 4 of the questionnaire) the biggest benefit of the completed mentoring course (quantification of open answers) to be the application of new methods in teaching $(33.3 \%)$, viewing their work from other perspectives and realization of changes in their work stereotypes $(26.7 \%)$, increased quality of own teaching, more effective utilization of mastered competencies, professional development (20\%), ability to better set objectives and plan teaching (16.7\%).

In their own mentoring practice, having completed the mentoring course, they mainly manage to listen actively to the client (46.7\%), build a relationship with the client based on trust $(33.3 \%)$, set objectives $(20 \%)$, create a favourable and safe environment $(16.7 \%)$, manage the client's development, mobilize their strengths and stimulate them $(16.7 \%)$.

\begin{tabular}{|c|c|c|c|}
\hline $\begin{array}{l}\text { Questionnaire } \\
\text { item }\end{array}$ & $\begin{array}{l}\text { Perceived benefit and utilization level of } \\
\text { the mentoring }\end{array}$ & Mean & $\begin{array}{l}\text { St. } \\
\text { deviation }\end{array}$ \\
\hline \multicolumn{4}{|c|}{ To what extent does the mentor utilize their mentoring skills in their school? } \\
\hline 15 & $\begin{array}{l}\text { To what extent do you utilize your } \\
\text { mentoring skills in your school? }\end{array}$ & 3.200 & 1.127 \\
\hline 16 & $\begin{array}{l}\text { To what extent does the management of } \\
\text { your school create conditions for your } \\
\text { mentoring work? }\end{array}$ & 3.167 & 1.234 \\
\hline \multirow[t]{2}{*}{18} & $\begin{array}{l}\text { To what extent do your colleagues require } \\
\text { your support in the area of mentoring? }\end{array}$ & 2.500 & .938 \\
\hline & Mean value & 2.956 & .958 \\
\hline \multicolumn{4}{|c|}{$\begin{array}{l}\text { What is the level of influence of the mentor's pedagogical work by the } \\
\text { mentoring? }\end{array}$} \\
\hline 17 & $\begin{array}{l}\text { To what extent have your changed your } \\
\text { work? }\end{array}$ & 3.367 & .928 \\
\hline \multirow[t]{2}{*}{21} & $\begin{array}{l}\text { To what extent has your mentoring } \\
\text { education influenced you in your } \\
\text { pedagogical work? }\end{array}$ & 3.833 & .950 \\
\hline & Mean value & 3.600 & .885 \\
\hline \multicolumn{4}{|c|}{ To what extent does the mentor regard the mentoring as important? } \\
\hline 20 & $\begin{array}{l}\text { To what extent would you recommend } \\
\text { your colleague to become a mentor? }\end{array}$ & 3.667 & 1.093 \\
\hline \multirow[t]{2}{*}{23} & $\begin{array}{l}\text { To what extent have your expectations } \\
\text { been fulfilled? }\end{array}$ & 3.467 & 1.106 \\
\hline & Mean value & 3.567 & 1.023 \\
\hline
\end{tabular}

Table 5: Perceived benefit and utilization level of the mentoring

They perceive the main reservations and limits in mentoring work to be colleagues' lack of interest in mentoring, convincing colleagues to cooperate and establish client contact $(26.7 \%)$, posing of strong questions $(20 \%)$, insufficient time for mentoring due to other pedagogical commitments $(16.7 \%)$ and planning and setting objectives with the client $(13.3 \%)$.

The results of the research point out a mutual connection between the level of mastery of professional coaching competencies, perception of oneself as a mentor, benefit of mentoring and its further utilization in own practice (Table 6). The extent to which the teachers perceive mentoring as beneficial is closely related to the extent to which they have mastered professional coaching competencies $(\mathrm{r}=.579, \mathrm{p}=.001)$, the extent to which they feel they are mentors $(\mathrm{r}=.577, \mathrm{p}=.001)$ and how they continue to utilize mentoring in practice $(\mathrm{r}=.543, \mathrm{p}=.002)$. The extent to which the teachers feel they are mentors after completing the course is closely related to the level of mastery of professional coaching competencies $(\mathrm{r}=.687, \mathrm{p}<.001)$ and both are also related to the further utilization of mentoring in practice $(r$ $=.468, \mathrm{p}=.009 ; \mathrm{r}=.443, \mathrm{p}=.014)$.

The teachers' level of mastery of professional coaching competencies is also connected to the extent to which the teachers are intrinsically motivated to participate in the mentoring course $(r=.425, p=.019)$. However, the extent of this inner motivation is not further related to how much the teachers feel they are mentors after completing the course $(r=.359$, $p$ $=.052$ ), how much they perceive the mentoring as beneficial $(\mathrm{r}=.331, \mathrm{p}=.074)$ and how much they continue to utilize it in practice $(\mathrm{r}=.268, \mathrm{p}=.152)$. 


\begin{tabular}{|l|c|c|c|c|c|}
\hline & $\begin{array}{c}\text { Self- } \\
\text { motivation }\end{array}$ & Mentor & $\begin{array}{c}\text { Professional } \\
\text { coaching } \\
\text { competencies }\end{array}$ & $\begin{array}{c}\text { Utilization } \\
\text { of } \\
\text { mentoring }\end{array}$ & $\begin{array}{c}\text { Benefit of } \\
\text { mentoring }\end{array}$ \\
\hline $\begin{array}{l}\text { Self- } \\
\text { motivation }\end{array}$ & - & & & & \\
\hline Mentor & .359 & - & & & \\
\hline $\begin{array}{l}\text { Professional } \\
\text { coaching } \\
\text { competencies }\end{array}$ & $.425^{*}$ & $.687^{* *}$ & - & & \\
\hline $\begin{array}{l}\text { Utilization of } \\
\text { mentoring }\end{array}$ & .268 & $.468^{* *}$ & $.443^{*}$ & - & \\
\hline $\begin{array}{l}\text { Benefit of } \\
\text { mentoring }\end{array}$ & .331 & $.577^{* *}$ & $.579^{* *}$ & $.543^{* *}$ & - \\
\hline$* *$ correlation at significance level.01, ${ }^{*}$ correlation at significance \\
level.05
\end{tabular}

Table 6: Correlation of self-motivation, mentor, professional coaching competencies, utilization of mentoring, benefit of mentoring (Pearson Correlation)

\section{Discussion}

In large part, the teachers participated in the mentoring course under the influence of the school's requirement, and the level of inner motivation to participate in the mentoring course it is represented in various degrees. It shows that the more the teachers are required to participate in the training by the school, the lower their level of inner motivation is. We can interpret the low level of teachers' self-motivation for the training, and strong pressure by the school, as risk factors of the realized methodical support's efficiency, as inner motivation for the mentoring training is key for the effective progress and results of the mentoring (compare with Lazarová et al, 2006; Šneberger, 2012a; Hrbáčková et al, 2014), just like inner motivation to utilize mentoring support on the client's part (Malásková, 2015). Thus, we encounter opposing approaches to methodical support intrinsically motivated teachers, and teachers on whom pressure is developed by the school and whose inner motivation is not very high. If a teacher accepts the mentoring merely on the basis of a recommendation or order from the school management, a situation where the role of mentor is not accepted may arise. Thus, the mentee does not accept the mentor as a person who should direct them and show them other possible ways of solving situations in often unforeseeable pedagogical practice. (Malásková, 2015)

Teacher's motivation for education is one of the most important factors of the efficiency of further education, as it is closely related to teachers' conduct, and to their willingness and preparedness to take useful information and stimuli away from the educational process and use them to innovate their own practice (Lazarová et al, 2006). In particular, teachers need inner motivation and methodical support which will respect the methods by which teachers teach, but also those by which they themselves learn (Strategie vzdělávací politiky České republiky do roku 2020, 2014).

At the same time, the results of the research show a very low level of awareness of mentoring before completing the course, whereby it shows that the higher the teachers' inner motivation level is, the more information they have before the mentoring course. At the same time, however, the teachers' level of awareness is not related to whether participation in the course was required by the school or not. We believe that it's essential for teachers to be informed about mentoring before participating in the training, especially if the training is required by the school. However, the question remains whether a higher level of awareness would lead to a higher level of self-motivation for the training; however, it's alarming and ineffective in terms of the school's quality and education when teachers are sent on training about which they know little.

Although the circumstances of entering a course are varied, from other research results it is evident that after completing a mentoring course teachers evaluated it mainly positively. In their own opinion they have mastered professional coaching competencies at a very good level.

After the training, the teachers state that they manage to utilize the acquired knowledge and skills in practice, create a favourable environment for work with the client, build a mutual relationship of trust and closeness. Moreover, the teachers also identify with their own mentoring position, because only some feel that they are mentors after completing the training. During contact with the client, the teachers believe that they manage to utilize active listening, but they are less sure about posing strong questions, which encourage new discoveries and insights into situation, and which do not offer clear answers. In this case knowledge of the issue is important, as well as training via interviews. Most teachers manage to plan and set objectives with the client, while some still perceive reservations in this area, just like in managing the client's development and responsibility, and developing their self-awareness. This observation goes along with results of Lopez-Real and Kwan (2005), who investigated constructs that lead to professional development, namely learning through selfreflection. The afore-mentioned area forms a very important part of the mentor's work in the process of guiding the mentee, which is why in this respect it's particularly necessary to take into account an individual approach to the mentee.

The teachers perceive the course itself as beneficial, as in addition to mastering professional client coaching competencies, it also allowed them to view their work from a new perspective, apply new methods in teaching, and increase the quality of their own teaching, which other experts and their studies also point out (Hobson, 2003; Moore, 2001; Šneberger, 2012b).

Similarly, other international studies show that mentoring experience contributes to the fact that teachers feel to be more experienced in their profession and perceive their work as more meaningful (Carger, 1996). Mentors feel contented particularly from helping less experience colleagues (Scott, 1998). At the same time, they perceive contribution to mentoring as a way of giving back to the teaching profession (Boreen et al, 2000).

Many teachers would also recommend their colleagues to become mentors. However, in this context, teachers point out their colleagues' lack of interest in mentoring, the low need to significantly change their work, the need to convince their colleagues to cooperate, and the demands of establishing client contact.

In actual practice, the teachers only make partial use of the acquired mentoring skills. They perceive a major obstacle in the lack of time for the realization of the mentoring due to other work obligations, and limits on the school's part, whereby we return once again to the initial issue of the creation of adequate conditions (a favourable work climate) for mentoring by the school, and to teachers' inner motivation to realize the mentoring. Thus, it is crucial to understand the true meaning of mentoring support when introducing the mentoring system in schools. This should not be misused in favour of the norm (e.g. evaluation of the quality of the teacher's performance), but 
instead should be construed as positive feedback and a good opportunity to develop self-regulation. Similarly, some foreign studies suggest that mentoring does not only affect the quality of teaching, but also affects the mentors themselves (Gordon and Maxey, 2000).

On the basis of the realized research, we can state that selfmotivation does not have a direct effect on the perception of the mentoring's efficiency (benefit of mentoring, utilization of mentoring in practice, the extent to which they feel they are a mentor), but a key role is apparently played by professional coaching competencies, which can be one of the mediating factors between inner motivation to participate in the course and the mentoring's perceived efficiency. The more intrinsically motivated the teachers are to participate in the mentoring course, the higher the level of professional coaching competencies they attain. The higher the level of mastery of professional coaching competencies the teachers attain, and the better mentors they feel they are, the more they perceive mentoring as beneficial, and the more they continue to use it in practice. Stanulis and Weaver (1998) emphasize that mentoring leads to a critical evaluation of one's own practise, which contributes to a greater awareness of the complexity of teaching.

\section{Conclusion}

In a modern school a teacher holds several roles; teacher is a very important person who strongly shapes the individual from childhood. That is why teachers are required to continuously improve their knowledge and skills, and thereby also their competencies. One professional development option is mentoring.

The contribution familiarizes us with the issue of utilizing mentoring in primary and secondary schools in the Zlín region, Support of professional development does not only relate to graduates and trainee teachers; it is necessary and important in every stage of teacher's career path.

Although the teachers evaluate the completed mentoring course as beneficial, they perceive a number of reservations after its completion, and feel that they are mentors only in part. The research shows that an important role is played by motivation to utilize mentoring support, and the associated system of introducing mentoring in schools. The teachers' obligation to participate in the mentoring programme is essential; nevertheless, it loses its meaning if it lacks the principle of voluntariness, as inner motivation to participate in the course has shown to be key for mastering professional coaching competencies. If the teachers feel that they attain higher professional coaching competency levels, they feel that they are better mentors, they regard the mentoring as more beneficial, and they use it more in practice.

Every teacher feels reservations in a different area of their own mentoring work, and mentoring is thus an ideal and crucial form of assistance, as it is based on individual needs and individual mentors' requirements, and can remove the perceived reservations. A teacher can benefit significantly from mentoring support by improving their qualities, always moving forward, and becoming a true expert in their profession.

\section{Acknowledgements}

The study originated as part of the IGA project IGA/
FHS/2013/008 - Mentoring as a Methodical Support of Primary and Secondary School Teachers in the Zlin Region.

\section{References}

Boreen, J., Johnson, M. K., Niday, D., and Potts, J. (2000) Mentoring beginning teachers: guiding, reflecting, coaching. York, Maine: Stenhouse Publishers.

Brumovská, T. and Seidlová Málková, G. (2010) Mentoring. Výchova k profesionálnímu dobrovolnictví, Praha: Portál.

Carger, C. L. (1996) The two bills: Reflecting on the gift of mentorship, Peabody Journal of Education, Vol. 71, No. 1, pp. 22-29. http://dx.doi.org/10.1207/s15327930pje7101_4

Clutterbuck, D. (2004) Everyone Needs a Mentor. Edition $4^{\text {th }}$, London: CIPD, [Online], Available: http://books.google.cz/boo $\mathrm{ks} ? \mathrm{id}=4 \mathrm{OYegB6}$ lbQAC\&printsec $=$ frontcover $\# \mathrm{v}=$ onepage $\& \mathrm{q} \&$ $\mathrm{f}=$ false [02 Jul 2016].

Competent Educators of the 21st Century: ISSA'S Principles of Quality Pedagogy (2010) International Step by Step Association, [Online], Available: http://www.issa.nl/sites/default/files/ Quality-Principles-final-WEB.pdf [15 Sep 2015].

Dlouhodobý záměr vzdělávání a rozvoje vzdělávací soustavy České republiky na období 2011 - 2015 (2011) MŠMT, [Online], Available: http://www.msmt.cz/vzdelavani/skolstviv-cr/dlouhodoby-zamer-vzdelavani-a-rozvoje-vzdelavacisoustavy-1 [09 Sep 2016].

DuBois, D. L., Karcher, M. J. Eds. (2006) Handbook of Youth Mentoring. London: Sage Publishing.

EDOST (2012) Mentoring ve firemni praxi, [Online], Available: http://kvalitalektoru.ohkcv.cz/files/metodicke-listy/ Studijn\%C3\%AD\%20materi\%C3\%A11\%20-\%20mentoring. pdf [07 Feb 2014].

Evertson, C. and Smithey, M. (2000) Mentoring Effectsisepen Proteges Classroom Practise: An Experimental Field Study, The Journali http://dx.doi.org/10.1080/00220670009598721

Gordon, S. and Maxey, S. (2000) How to help beginning teachers succeed. 2nd ed. Alexandria, VA: Association for Supervision and Curriculum Development.

Hawkins, L. C. (1950) Measurements of Efficiency, Oxford Economic Papers, New Series, Vol. 2, No. 1, pp. 30-50.

Hobson, A. (2003) Mentoring and Coaching for New Leaders, NCSL, [Online], Available: http://www.rtuni.org/uploads/docs/ mentoring-and-coaching-for-new-leaders-summary.pdf $\quad[05$ Aug 2016].

Hrbáčková K., Suchánková, E., Lukášová, J. and Duhárová, D. (2014) Mentoring jako metodická podpora vzdélávání učiteli̊, Zlín: Univerzita Tomáše Bati ve Zlíně, Fakulta humanitních studií.

Huling, R. L. (2001) Teacher Mentoring as Professional Development. ERIC Digest, 2001, ERIC Clearinghouse on Teaching and Teacher Education Washington DC, [Online], Available: http://www.ericdigests.org/2002-3/mentoring.htm [26 Nov 2016]. ED460125.

ICF (2013) Základní kompetence profesionálního koučování. ICF Czech Republic, [Online], Available: https://www. coachfederation.cz/cz/pro-klienty/kompetence-icf-kouce.html [17 Jun 2015].

Ingersoll, R. and Smith, T. (2004) Do Teacher Induction and Mentoring Matter? National Association of Secondary School Principals, NASSP Bulletin, Vol. 88, No. 638, pp. 28-40. http:// dx.doi.org/10.1177/019263650408863803

Irvin, J. J. (1985) The Master Teacher as Mentor: Role Perceptions of Beginning and Master Teacher, Education, Vol. 106, No. 2, pp. 123-130. 
Jonson, K. F. (2008) Being an effective mentor: How to Help Beginning Teachers Succeed, CA: Corwin Press.

Kompetentni učitel 21. století: Mezinárodní profesní rámec kvality ISSA (2011) Praha: Step by Step ČR, o.s.

Kraus, J. et al (2005) Nový akademický slovník cizích slov $A-Z ̌$, Český Těšín: Academia.

Lazarová, B. et al (2006) Cesty dalšiho vzdělávání učiteli̊, Brno: Paido.

Lepková, M. (2015) Mentoring jako nástroj profesního rozvoje učiteli̊ základních a středních škol ve Zlínském kraji, Zlín: Univerzita Tomáše Bati ve Zlíně. Thesis.

Lopez-Real, F. and Kwan, T. (2005) Mentors' perceptions of their own professional development during mentoring, Journal of Education for Teaching: International Research and Pedagogy, Vol. 31, No. 1, pp. 15-24. https://doi. org/10.1080/02607470500043532

Malásková, Z. (2015) Mentoring ako metodická podpora učitel'ov na základných a stredných školách v Zlínskom kraji, Zlín: Univerzita Tomáše Bati ve Zlíně. Thesis.

Medlíková, O. (2013) Lektorské dovednosti: manuál úspěšného lektora, $2^{\text {nd }}$ edition, Praha: Grada.

Mezinárodní pedagogické ISSA standardy (2002) Praha: Step by Step ČR, o.s.

Mezinárodní standard práce učitele a lektora RWCT (2007) Praha: Kritické myšlení, o. s., [Online], Available: http://www. msmt.cz/standarducitele/ukazky-zahranicnich-standardu [09 Aug 2016].

Moore, K. B. (2001) Mentoring and coaching teachers, Early Childhood Today, Vol 16, No. 3, p15.

Národni program rozvoje vzdělávání v České republice: Bílá kniha (2001) Praha: Ústav pro informace ve vzdělávání.

National Academy of Sciences (1997) Adviser, teacher, role model, friend, Nap.edu, [Online], Available: http://www.nap. edu/openbook.php?record_id=5789\&page=R1 [05 Oct 2013].

Nový termín - mentoring (2009) Učitelské noviny, [Online], Available: http://ucitelskenoviny.cz/?archiv\&clanek=1904 [13 Jan 2014].

NÚV: Národní ústav pro vzdělávání, (2011-2015) Cesta ke kvalitě. Autoevaluace školy [Online], Available: http://www. nuv.cz/uploads/DVD/html/index.html [26 Feb 2014].

Píšová, M., Duschinská, K. et al (2011) Mentoring v učitelství, Praha: Univerzita Karlova v Praze, Pedagogická fakulta.

Pol, M. (2007) Škola v proménách, Brno: Masarykova univerzita. Průcha, J., Walterová, E. and Mareš, J. (2009) Pedagogický slovník, Praha: Portál.

Rhodes J. and DuBois, D. L. (2008) Mentoring relationships and programs for youth, Current Directions in Psychological Science, 17, [Online]. Available: http:/www.rhodeslab.org/ files/RHODESDUBOISCURRENTDIRECTIONS.pdf [24 Mar 2014]. http://dx.doi.org/10.1111/j.1467-8721.2008.00585.x

Scott, N. H. (1998) Careful planning or serendipity? Promoting well-being through teacher induction. Paper presented at the Annual Meeting of the Canadian Society for the Study of Education, Ottawa, Canada. ED 420627.

Shea, G. (2002) Mentoring: How to Develop Successful Mentor Behaviors, USA: Axzo Press.

Šneberger, V. (2012a) Co je mentoring a jeho zavádění na škole, Ostrava: Repronis.

Šneberger, V. (2012b) Metodika práce s kompetenčním modelem, Ostrava, Projekt OPVK Podpora pedagogů koučováním jako nástroj efektivního řízení procesů ve školách MSK, reg. no. CZ.1.07/1.3.05/03.0024.

Šneberger, V. (2012c) Výcvik interních mentorů: príručka, Ostrava: Repronis.
Stanulis, R., and Weaver, D. (1998) Teacher as mentor, teacher as learner: lessons from a middle-school language arts teacher. The Teacher Educator, Vol. 34, No. 2, pp. 134-143. http://dx.doi. org/10.1080/08878739809555192

Strategie vzdělávaci politiky České republiky do roku 2020 (2014) MŠMT, Strategie vzdělávání 2020, [Online], Available: http://www.vzdelavani2020.cz/images_obsah/dokumenty/ strategie-2020_web.pdf [06 Aug 2016].

Syslová, Z. (2013) Profesni kompetence učitele mateřské školy, Praha: Grada.

Tomková, A. et al (2012) Rámec profesnich kvalit učitele. Hodnotíci a sebehodnotici arch, Praha: Národní ústav pro vzdělávání.

Zachary, L. (2009) The Mentee's Guide: Making Mentoring Work for You, San Francisco: Pfeiffer. 